\title{
The Transfer Of Productive Land For Industrial Interest
}

\author{
Asep Hermawan*) \\ ${ }^{*}$ Indonesian National Police of Cirebon, E-mail: \\ asephermawancrb2020@gmail.com
}

\begin{abstract}
This study aims to analyze \& study the regulation of the practice of converting productive land into industrial land which often occurs in regions as the regional economy advances. The research uses a sociological juridical approach. Based on the research it was concluded that not all of the conversion of agricultural land to industrial areas can balance the food sector with the industrial sector. Act No. 5 of 1960 concerning Basic Agrarian Regulations, Act No. 41 of 2009 concerning Protection of Agricultural Land for Sustainable Food, \& Government Regulation no. 1 of 2011 concerning the Determination \& Transfer of Agricultural Land for Sustainable Food has clearly stated that the conversion of productive land can only be carried out for the public interest so that industrial interests are the exception, so that the regulation can balance the food sector.

Keywords: Validity; Transfer; Functions; Productive; Land; Industrial.
\end{abstract}

\section{Introduction}

Land conversion or conversion of agricultural land is actually not a new problem. Population growth \& economic growth require infrastructure development in the form of roads, industrial buildings \& settlements. This of course must be supported by the availability of land. Conversion of agricultural land is usually carried out directly by the land owner or indirectly by other parties, which previously began with the sale \& purchase of agricultural land. ${ }^{1}$ In fact, agricultural land has a strategic role $\&$ function as a basic resource in land-based agriculture. ${ }^{2}$ Land has a very important meaning in human life. The elements contained in the soil are very meaningful in human life. So that land is one of the primary needs for humans. Land is something that is a place for all activities or activities of life \& human life. In fact, land plays a major role in efforts to improve community welfare. ${ }^{3}$

Citarum watershed produces $40.95 \%$ of the total rice of Prov. West Java, but the area of rice fields has decreased. In the period 2008-2015, $118.71 \mathrm{~km} 2$ of agricultural land was converted. Regency. For example, in Bogor, agricultural land has decreased by

\footnotetext{
${ }^{1}$ Laeli Nurchamidah \& Djauhari, "Pengalihfungsian Lahan Pertanian Ke NonPertanian Di Kabupaten Tegal”. Jurnal Akta Vol. 4 No. 4 December, 2017, p. 700, http://jurnal.unissula.ac.id/index.php/akta/article/view/2513/1876

${ }^{2}$ Gesthi Ika Janti, Edhi Martono, Subejo, 2016, "Perlindungan Lahan Pertanian Pangan Berkelanjutan Guna Memperkokoh Ketahanan Pangan Wilayah, Studi Kasus di Kabupaten Bantul DIY", Jurnal Ketahanan Nasional, Vol. 22, No. 1, p. 1-21.

${ }^{3}$ Abdul Kodir, Amin Purnawan \& Akhmad Khisni, Problems \& Implementation of Government Regulation Number 1 of 2011 Regarding the Transfer of Function of Agricultural Land to Industrial Land, Sultan Agung Notary Law Review (SANLaR) Volume 3 No. 1, March 2021, p. 182
} 
$2.26 \%$ every year. ${ }^{4}$ Many factors influence land owners to convert land or sell their agricultural land, including land prices, income proportions, land area, land productivity, land status \& government policies. Now farmers or agricultural land owners as well as agricultural land cultivators are no longer dealing with landlords as in the era of the 1960 BAL, but dealing with large capital in industry as well as rich people in the city who buy land in suburban \& suburban areas. Agricultural land has changed in value into shares which can be traded at any time through the capital market. So that land transactions mean reaching $\&$ crossing national territorial boundaries. ${ }^{5}$

The threat to the disruption of food security as a result of the rampant conversion is very significant. Many areas that were previously self-sufficient in rice have now become regions that import rice from other regions. This threat to food security will not only reduce rice production but will also disrupt economic, social, political stability \& population development in general. ${ }^{6}$ In the context of sustainable agricultural development, the protection of agricultural land for food is an effort that is inseparable from agrarian reform which includes efforts to organize, control/ownership related to the legal relationship between humans \& land. ${ }^{7}$ Provisions for the protection of sustainable food agricultural land are intended so that certain land parcels may only be used for appropriate food agriculture activities.

Government Regulation No. 1 of 2011 concerning the Determination \& Transfer of Functions of Agricultural Land for Sustainable Food in Article 3 it is explained that the purpose of controlling the conversion of agricultural land is to realize \& ensure the availability of Sustainable Food Agricultural Land, to realize self-reliance, resilience, \& national food sovereignty, to increase empowerment, income \& welfare for farmers, providing business certainty for farming business actors, realizing ecological balance $\&$ preventing investment in agricultural infrastructure from being wasted.

Against the transfer of land functions according to Government Regulation no. 1 of 2011 concerning the Determination \& Transfer of Functions of Sustainable Food Agricultural Land in article 35 has limitedly regulated that land that has been designated as Sustainable Food Agricultural Land is protected \& prohibited from being converted. The transfer of land functions can be carried out by the regional government in the context of land acquisition for the public interest or a disaster occurs. Meanwhile, the interests Industry is not included in the public interest which is allowed to use paddy fields (productive land) for conversion.

A land can be said to be a sustainable food agricultural land if the land is able to produce food that meets food needs not only in the area. Sustainable food agricultural land can supply the food needs of the surrounding area. In practice, Government Regulation Number 1 of 2011 concerning the Determination \& Transfer of Agricultural

\footnotetext{
4 Wilmar Salim, Pusat Penelitian Infrastruktur \& Kewilayahan Instutute Teknologi Bandung, http://bappeda.jabarprov.go.id/wp-content/uploads/2020/10/PPIK-ITB-paparan-Bappeda-Jabar091020.pdf

${ }^{5}$ Mustofa Suratman, 2013, Penggunaan Hak Atas Tanah Untuk Industri, Sinar Grafika, Jakarta, p. 8

${ }^{6}$ Nana Apriyana, Kebijakan Konversi Lahan Pertanian dalam Rangka Mempertahankan Ketahanan Pangan, Studi Kasus di Pulau J awa, Kementerian Perencanaan Pembangunan Nasiona/Bappenas, Jakarta, 2011, p. 5

${ }^{7}$ Maria SW Sumarjono, Tanah dalam Perspektif Hak Ekonomi, Sosial \& Budaya, Kompas Gramedia, Jakarta, 2008, p. 95
} 
Land for Sustainable Food is often circumvented by draining productive land so that agricultural land seems to become ordinary land in order to obtain permits for the implementation of land conversion.

This study aims to analyze \& examine the regulation of the practice of converting productive land into industrial land which often occurs in regions as the regional economy advances.

\section{Research Methods}

This research used Sociological Juridical Approach, with data sources used in this study include primary data \& secondary data. Primary data were taken using semistructured interviews. Secondary data is obtained by conducting a documentation study of the laws \& regulations, literature books \& other documents related to the object or research material. The method of data analysis in this study used qualitative descriptive.

\section{Results \& Discussion}

\subsection{Application of Transfer of Productive Land}

The state through its bureaucratic machine is the focus of policy formulation \& is the determining factor of a state. Futuristic policies made by the government occupy the top priority for solving community problems, especially those concerning spatial planning issues that have a very high level of dynamics. The regulation of the use of space \& territory is based on Article 33 paragraph (3) of the 1945 Constitution which reads "Earth, Water \& Natural Resources contained therein are controlled by the State $\&$ used for the greatest prosperity of the people" (Republic of Indonesia, Constitutional Law). 1945, Chapter XIV article 33 paragraph 3). It is further regulated in various laws \& regulations of the central \& regional governments. ${ }^{8}$

Land resources in their use $\&$ utilization are included in the state property model or state property. This means that land, including the natural wealth contained therein, within the territory of the Republic of Indonesia, as a gift from God Almighty is the earth, water \& space of the Indonesian nation \& is a national wealth. So it is an obligation for the Indonesian people to manage it which is aimed at realizing justice, welfare \& happiness for all Indonesian people, $\&$ is obliged to preserve their lives. Article 2 of the UUPA is the embodiment of the mandate of Article 33 paragraph (3) of the 1945 Constitution that the earth, water \& space, including the natural resources contained therein, are controlled by the State. This has become a national political policy in the land sector, which mandates that the state controls the earth, water, \& the wealth contained therein $\&$ its use is solely aimed at realizing prosperity for all the people of Indonesia. Based on the provisions of Article 2 paragraph (4) of the LoGA, the authority of the state's right to control can be delegated to the Regional Government as necessary \& does not conflict with the LoGA \& higher regulations. The formation of the UUPA is based on Pancasila as a philosophical basis, there are articles containing the precepts of Social Justice for All Indonesian People. These precepts are described in article 6, article

\footnotetext{
${ }^{8}$ Eka fitrianingsih, 2017, Tinjauan terhadap Alih Fungsi Tanah Pertanian ke non Pertanian (permukiman) di Kecamatan Tomoni Kabupaten Luwu Timur, Faculty of Law, Universitas Hasanudin Makassar.
} 
7, article 10 paragraph (1), article 11 paragraph (2), article 13, article 15 , article 17, article $18, \&$ article 53 . The authority of the right to control from the state can be delegated to the regional government as necessary \& not contrary to the UUPA \& higher regulations.

Based on article 2 of Act No. 26 of 2007 concerning Spatial Planning, spatial planning is carried out based on the principles of integration, harmony, harmony, balance, sustainability, usability, effectiveness, openness, togetherness, partnership, protection of public interests, legal certainty, justice \& accountability. However, in Article 20 paragraph (3), paragraph (4), \& paragraph (5) of Act No. 26 of 2007 concerning Spatial Planning regarding the period of spatial planning, it becomes a gap to commit violations of land conversion. This article is the basis for the establishment of the review of the spatial plan 1 (one) time in 5 (five) years. The review of the spatial plan is an effort to see the compatibility between the spatial plan \& development needs that take into account the development of the strategic environment \& internal dynamics, as well as the implementation of space utilization. Article 26 paragraph (4) wherein the district spatial plan as referred to in paragraph (1) is reviewed 1 (one) time in 5 (five) years. In this regard, the implementation of spatial planning in Pangenan District is evaluated once every 5 years by following existing conditions, this means that the state of agricultural land can change according to community needs \& regional developments.

Furthermore, the mandate of Article 44 of Act No. 41 of 2009 concerning the Protection of Sustainable Agricultural Land states that land that has been designated as Sustainable Food Agricultural Land is protected \& prohibited from being converted. Paragraph (2) states that in the case of public interest, sustainable food agricultural land may be converted. However, based on Presidential Regulation Number 65 of 2006 concerning Land Procurement for the Implementation of Development in the Public Interest which is an amendment to Presidential Regulation Number 36 of 2005, it is stated that industrial development carried out by a company is usually a Limited Liability Company in cooperation with investors not in the public interest sustainable food agricultural land if it is converted to industrial use is not allowed. ${ }^{9}$

Government in Government Regulation no. 1 of 2011 concerning the Determination \& Transfer of Functions of Sustainable Food Agricultural Land in article 3 aims to realize \& ensure the availability of Sustainable Food Agricultural Land, control the transfer of functions of Sustainable Food Agricultural Land, realize national food independence, resilience, \& sovereignty, increase empowerment, income \& welfare for farmers, providing business certainty for farming business actors, realizing ecological balance \& preventing investment in agricultural infrastructure from being wasted. Against the transfer of function Government Regulation no. 1 of 2011 concerning the Determination \& Transfer of Functions of Sustainable Food Agricultural Land in article 35 stipulates that land that has been designated as Sustainable Food Agricultural Land is protected \& prohibited from being converted.

Industry is not included in the public interest which is allowed to use paddy fields for conversion. A land can be said to be a sustainable food agricultural land if the land is

\footnotetext{
${ }^{9}$ Pramono J, Bakri A \& Soelaiman I. 2016. Persaingan Dalam Pemanfaatan Lahan Antara Sektor Pertanian \& Industri. Prosiding Lokakarya Persaingan dalam Pemanfaatan Sumberdaya Lahan \& Air: p. 157-176. Pusat Penelitian \& Pengembangan Sosial Ekonomi Pertanian \& Ford Foundation.
} 
able to produce food that meets food needs not only in the area. Sustainable food agricultural land can supply the food needs of the surrounding area. To prevent a reduction in the amount of rice production that is not only used for one area, the transfer of function activities must be regulated with policies that are more focused on protecting agricultural land for sustainable land so that there is legal certainty. The local government has the right \& indeed must make the sub-district as a form of accountability for the prosperity of its people.

The conversion of agricultural land to non-agricultural uses for industry requires the right solution in order to achieve justice by prioritizing common interests, namely increasing food production \& increasing the economic sector from the agricultural sector \& the industrial sector. It is necessary to protect farmers \& their farming businesses in the form of laws or government regulations so that farmers have economic incentives to work in the agricultural sector. National development policies must focus on the realization of a strong agricultural sector that does not tend to pursue high economic growth, especially regencies/cities with regional autonomy authorities. The participation of local governments \& communities needs to be increased in spatial planning plans to utilize land according to its designation so that social functions in achieving aspects of justice can be fulfilled. The district government with efforts to increase rice productivity that has been carried out so far can be wiser so that there will be no more loss of the agricultural sector so that food security can be achieved \& industrial needs can be implemented. ${ }^{10}$

Overall, the legal aspects related to the conversion of agricultural land have been sufficiently integrated to meet the criteria as a basis for consideration in terms of granting permits for conversion of functions for industrial estate development locations to entrepreneurs. It is the government through the BPPT instrument that should be able to play a central role in organizing \& regulating the application for the conversion of this productive agricultural land. Without the permits they issue, it is not possible for entrepreneurs to develop Industrial Estates or by means of land conversion. This stage of the applicant's permit application process to BPPT is very decisive whether the land conversion is obeyed or violated, which in practice in the field is strongly influenced by the environmental economy. , politics, \& others.

\subsection{Solving the Problem of Transfer of Productive Land for Industrial Interest}

With regard to law enforcement on the conversion of agricultural land, the central government \& regional governments still consider that development only encourages the improvement of physical infrastructure, which often sacrifices productive agricultural land. The conversion of agricultural land into residential areas, the development of public infrastructure $\&$ industrial facilities is quite worrying so that it will have an impact on national \& regional food crises if not taken seriously. In the midst of the food self-sufficiency target, there needs to be serious steps in law enforcement \& maximum protection of productive agricultural land.

\footnotetext{
${ }^{10}$ Irawan B. \& Friyatno. 2002. “Dampak Konversi Lahan Sawah di Jawa Terhadap Produksi Beras \& Kebijakan Pengendaliannya”. Jurnal Sosial-Ekonomi Pertanian \& Agribisnis Universitas Udayana, SOCA. 2(2):79-95.
} 
The conversion of agricultural land to non-agriculture can affect various aspects of life, including the decline in food production which causes food sovereignty to be threatened, the loss of farmers' livelihoods \& can lead to unemployment, \& the loss of investment in agricultural infrastructure (irrigation) which costs very high. Many regulations have been issued, but the commitment in implementing them is very minimal from the government \& local governments. Act No. 1 of 2009 concerning PLP2B is complemented by local government regulations. These regulations in their implementation have not been effective as can be seen from the conversion of agricultural land that continues to occur \& is increasingly uncontrolled. The economic incentives contained in the government regulations are still at the normative level,

If viewed carefully, there are 3 components involved in the transfer of land functions, namely the Government, investors \& the community, when viewed from the prism of the prismatic theory proposed by Mahfud MD, the government is faced with two interests, namely group interests \& individual interests. According to Mahfud MD, the character of the law that will affect the legal politics of a country will be largely determined by the choice of the value of interest, namely whether to prioritize individual prosperity or to prioritize the prosperity of many people. The distinction on whether or not the fulfillment of interests is based on a political economy perspective. Meanwhile, from a social theory perspective, even from an ideological perspective. ${ }^{11}$

In the previous discussion, it was clearly explained in Government Regulation Number 1 of 2011 concerning the Determination of Sustainable Agricultural Land Transfers that the conversion of agricultural land for industrial purposes is not justified so that there is no justification for deviations from any practice, especially by deceiving or converting agricultural land into land unproductive dry. The role of law enforcement is very crucial to provide a deterrent effect \& practice deviant practices in an effort to protect agricultural land so that land is not converted.

If we look at Lawrence M. Friedman's theory, there are 3 (three) factors that greatly influence law enforcement, namely as follows: a) Legal Substance or legal substance; b) Legal Structure or legal structure, including its institutions; c) Legal Culture or legal culture. ${ }^{12}$ Friedman's theory can be used as a parameter why law enforcement in Indonesia, in terms of controlling the conversion of agricultural land, is not running effectively.

The effectiveness of the law is shown by the choice to use the law which depends on the level of compliance of the community. The law will be effective if people actually act in accordance with legal norms as they have to do, that the norms are properly applied \& obeyed. In Indonesia, compliance with the law depends on how much the law is valid $\&$ believed by the community as a legal force that binds their behavior. one that affects law enforcement, especially the problem of land use change, is related to the legal structure or legal structure, this occurs due to the lack of coordination \&

\footnotetext{
${ }^{11}$ Mahfud MD. Membangun Politik Hukum Men-egakkan Konstitusi, Jakarta, PT Raja Grapindo Persada, 2011, p. 23-24.

12Joko Kris Sriyanto \& Bambang Tri Bawono, "Effectiveness of Performance of Prosecutor's Office in Preventing Corruption Crime after the Team's Disbandment", dalam Law Development Journal Volume 2 Issue 4, December 2020, p. 613. http://jurnal.unissula.ac.id/index.php/ldj/article/view/14740/5391
} 
consolidation between related institutions/agencies in carrying out policies to control the conversion of agricultural land to non-agriculture.

In addition, there is a lack of understanding among law enforcers related to the agrarian sector regarding Article 33 paragraph 3 of the 1945 Constitution Juncto Article 2 of the UUPA where it is emphasized that all natural resources in Indonesia, be it earth, water \& space, are used for the greatest prosperity of the people. Due to lack of understanding of these regulations, the government or law enforcement officers in the agrarian sector easily give permission to transfer agricultural land functions under the pretext of increasing PAD \& the interests of a group of people without paying attention to the interests of small communities \& not caring about sustainable agricultural land.

\section{Closing}

Not all of the implementation of the conversion of agricultural land to industrial areas can balance the food sector with the industrial sector. Act No. 5 of 1960 concerning Basic Agrarian Regulations, Act No. 41 of 2009 concerning Protection of Agricultural Land for Sustainable Food, \& Government Regulation no. 1 of 2011 concerning the Determination \& Transfer of Functions of Agricultural Land for Sustainable Food has been able to balance the food sector while Act No. 26 of 2007 concerning Spatial Planning has not fully balanced the conversion of agricultural land to non-agriculture because there is a review every 5 (years) 1 (one time. There are no sanctions for violators who carry out land use changes that are not in accordance with Government Regulation No. 1 of 2011. The norms for the protection of productive land conversion have been clearly determined in various laws \& regulations so that implementation at the policy level should adjust to the existing basic norms. Existing interests must be placed in the corridors for the benefit of the legislation on the conversion of productive agricultural land.

Determination of the amount of perpetual productive agricultural land (which is maintained) is also necessary to maintain the stability \& continuity of food supply by taking into account the population, the area of agricultural land that currently exists, the total area, population growth rate, economic growth targets, plus projected food needs in the future. The flow of land conversion permits, especially for the development of industrial estates, has not been centralized or coordinated in just one agency, in this case the BPPT (Integrated Licensing Service Agency) so that the entire application process seems unable to be monitored properly because inconsistencies in licensing approvals can still be found which can harm the permit applicant or public interest, in addition to the unpublished detailed mapping of the entire area. There needs to be firmness in the formulation of statutory norms regarding the protection of agricultural land in an effort to control the conversion of agricultural land, especially in the norm of imposing sanctions. Law enforcement against irresponsible perpetrators of agricultural land conversion violations is an important factor to provide a deterrent effect for perpetrators of land conversion violations.

\section{References}

Journals: 
[1] Abdul Kodir, Amin Purnawan \& Akhmad Khisni, Problems \& Implementation of Government Regulation Number 1 of 2011 Regarding the Transfer of Function of Agricultural Land to Industrial Land, Sultan Agung Notary Law Review (SANLaR) Volume 3 No. 1, March 2021

[2] Joko Kris Sriyanto \& Bambang Tri Bawono, "Effectiveness of Performance of Prosecutor's Office in Preventing Corruption Crime after the Team's Disbandment", dalam Law Development Journal Volume 2 Issue 4, December 2020, http://jurnal.unissula.ac.id/index.php/ldj/article/view/14740/5391

[3] Gesthi Ika Janti, Edhi Martono, Subejo, 2016, "Perlindungan Lahan Pertanian Pangan Berkelanjutan Guna Memperkokoh Ketahanan Pangan Wilayah, Studi Kasus di Kabupaten Bantul DIY", Jurnal Ketahanan Nasional, Vol. 22, No. 1.

[4] Irawan B. \& Friyatno. 2002. "Dampak Konversi Lahan Sawah di Jawa Terhadap Produksi Beras \& Kebijakan Pengendaliannya”. Jurnal Sosial-Ekonomi Pertanian \& Agribisnis Universitas Udayana, SOCA. 2(2).

[5] Laeli Nurchamidah \& Djauhari, "Pengalihfungsian Lahan Pertanian Ke NonPertanian Di Kabupaten Tegal”. Jurnal Akta Vol. 4 No. 4 December 2017 http://jurnal.unissula.ac.id/index.php/akta/article/view/2513/1876

\section{Books:}

[1] Eka fitrianingsih, 2017, Tinjauan terhadap Alih Fungsi Tanah Pertanian ke non Pertanian (permukiman) di Kecamatan Tomoni Kabupaten Luwu Timur, Faculty of Law, Universitas Hasanudin Makassar.

[2] Mahfud MD. Membangun Politik Hukum Men-egakkan Konstitusi, Jakarta, PT Raja Grapindo Persada, 2011

[3] Maria SW Sumarjono, Tanah dalam Perspektif Hak Ekonomi, Sosial \& Budaya, Kompas Gramedia, Jakarta, 2008.

[4] Mustofa Suratman, 2013, Penggunaan Hak Atas Tanah Untuk Industri, Sinar Grafika, Jakarta

[5] Nana Apriyana, Kebijakan Konversi Lahan Pertanian dalam Rangka Mempertahankan Ketahanan Pangan, Studi Kasus di Pulau J awa, Kementerian Perencanaan Pembangunan Nasiona/Bappenas, Jakarta, 2011

[6] Pramono J, Bakri A \& Soelaiman I. 2016. Persaingan Dalam Pemanfaatan Lahan Antara Sektor Pertanian \& Industri. Prosiding Lokakarya Persaingan dalam Pemanfaatan Sumberdaya Lahan \& Air . Pusat Penelitian \& Pengembangan Sosial Ekonomi Pertanian \& Ford Foundation.

Internet

[1] Wilmar Salim, Paparan, Pusat Penelitian Infrastruktur \& Kewilayahan Institute Teknologi Bandung, http://bappeda.jabarprov.go.id/wpcontent/uploads/2020/10/PPIK-ITB-paparan-Bappeda-Jabar-091020.pdf 